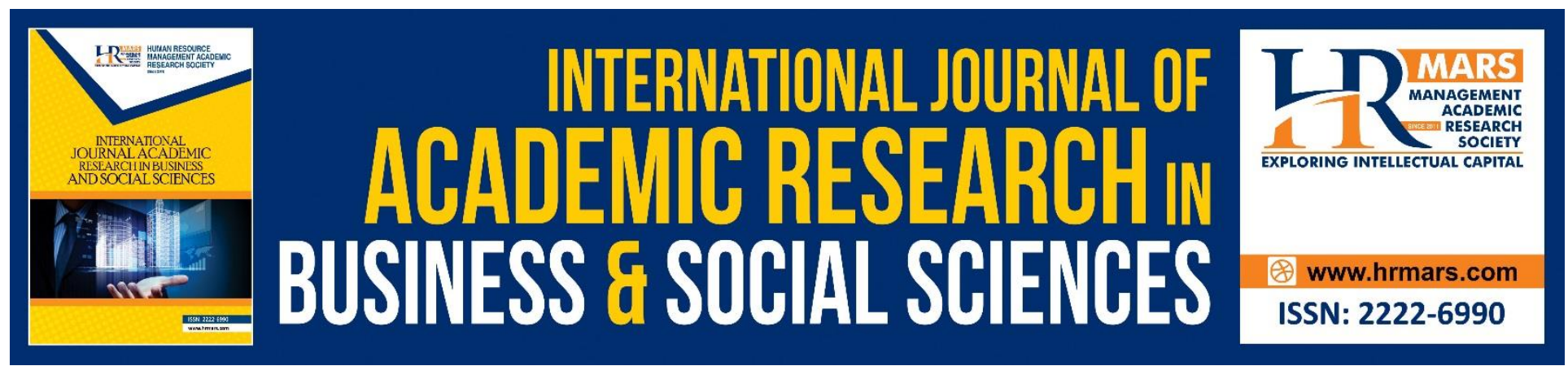

\title{
Comparative Analysis Between Traditional Villages and Felda Settlements on Solid Waste Management in Kota Tinggi District
}

\author{
Robiah Suratman
}

To Link this Article: http://dx.doi.org/10.6007/IJARBSS/v10-i11/8361

DOI:10.6007/IJARBSS/v10-i11/8361

Received: 01 October 2020, Revised: 26 October 2020, Accepted: 19 November 2020

Published Online: 29 November 2020

In-Text Citation: (Suratman, 2020)

To Cite this Article: Suratman, R. (2020). Comparative Analysis Between Traditional Villages and Felda Settlements on Solid Waste Management in Kota Tinggi District. International Journal of Academic Research in Business and Social Sciences, 10(11), 1373-1386.

\section{Copyright: (c) 2020 The Author(s)}

Published by Human Resource Management Academic Research Society (www.hrmars.com)

This article is published under the Creative Commons Attribution (CC BY 4.0) license. Anyone may reproduce, distribute, translate and create derivative works of this article (for both commercial and non-commercial purposes), subject to full attribution to the original publication and authors. The full terms of this license may be seen at: http://creativecommons.org/licences/by/4.0/legalcode

Vol. 10, No. 11, 2020, Pg. 1373 - 1386

Full Terms \& Conditions of access and use can be found at http://hrmars.com/index.php/pages/detail/publication-ethics 


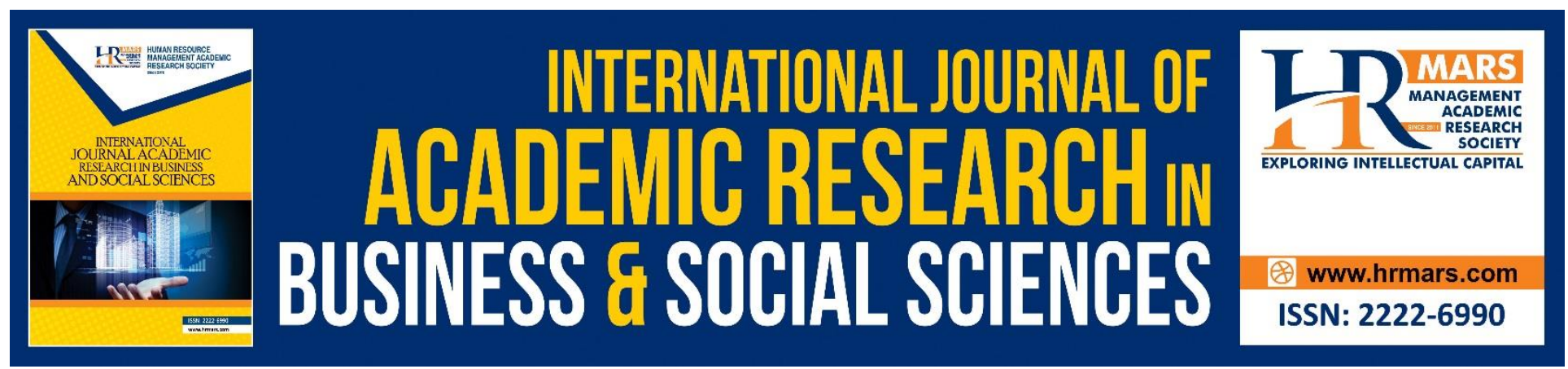

\title{
Comparative Analysis Between Traditional Villages and Felda Settlements on Solid Waste Management in Kota Tinggi District
}

\author{
Robiah Suratman \\ Faculty of Built Environment and Surveying, Universiti Teknologi Malaysia, 81310 UTM Johor \\ Bahru, Johor Malaysia
}

\begin{abstract}
Solid waste management (SWM) has an important role in enabling sustainability in developing countries. A systematic and proper management is an important aspect in maintaining a clean and safe environment. In Malaysia, SWM in areas outside the local authority (LA) boundary is non-existent. This paper made a comparative analysis of solid waste in that areas in terms of characteristics, management, and potential methods that can be applied. A study was conducted in 46 places which include traditional villages and FELDA settlements in Kota Tinggi district. The study found there is a lack of SWM in traditional villages compared to FELDA settlements. In traditional villages, $60.71 \%$ villagers use traditional methods like onsite burning, animal feed, or self-transferred to wheeled dustbins outside of their villages, while in FELDA settlements, the FELDA settlers apply modern methods i.e. hiring contractor for a proper waste collection. The Google Earth's zonal system was used to determine the road accessibility categorized as Zone A (57\%), Zone B (32\%), and Zone C (11\%). This study is in line with the government's aspiration to become a developed country without discarding the aspect of sustainable development.
\end{abstract}

Keywords: Household Solid Waste, Environmental Management, Sustainable Waste Management, Rural Development, Rural Community

\section{Introduction}

Waste management systems is one of the biggest challenges for sustainable development in many countries. In traditional system, waste is produced in the last phase of the product consumption cycle (Zaman, 2014). Waste generation differs according to countries of different economic status, where in this case the developed countries are the highest producers (Mohee et al., 2015). Other than institutional and commercial, household is one of the primary sources of waste in Malaysia (Tariq \& Mostafizur, 2007). The increasing household's solid waste generation has become a major problem due to activities concerning the control, collection, processing, and disposal of economic, social, and environmental policy (Indrianti, 2016). Thus, 
waste collection also is a vital functional element of the waste management system and an improper waste collection system completely disrupts the waste management flow (Mohee et al., 2015). It refers to the scrap materials and undesired excess and objects arising from any process required to be disposed of as it has been broken, torn, polluted, or otherwise damaged (Act 672, Solid Waste Management and Public Cleansing Act, 2007). The definition of solid waste of any other substance in accordance with this Act or any other written law required by the authority to be disposed of, but does not include scheduled wastes as described under the Environmental Quality Act 1974 (Act 127), sewage as defined in the Water Services Industry Act 2006 (Act 655), or radioactive waste as defined in the Atomic Energy Licensing Act 1984 (Act 304).

As such, Solid Waste Management (SWM) is a crosscutting issue that affects and impacts various areas of sustainable development in each of the three sustainability domains: ecology, economy, and society. The affected areas include living conditions, sanitation, public health, marine and terrestrial ecosystems, access to decent jobs, as well as the sustainable use of natural resources. Accordingly, out of 17 Sustainable Development Goals (SDGs) of the 2030 Agenda for Sustainable Development, adopted by the 193 UN Member States in September 2015 (United Nation, 2016), at least 12 SDGs and their pertinent targets have a direct link to SWM. Not being a high-level SDG in its own right could potentially threaten to reduce the 'visibility' of SWM as a political priority; however, United Nations Environment Programme (UNEP)'s recent Global Waste Management Outlook (GWMO) (Willson et al., 2015) developed the contrary argument, that the cross cutting nature of SWM and its impact on not just one but on 12 SDGs should only emphasise the importance and increase the political priority of SWM.

Specifically, SDG Target 11.6 is to reduce the adverse per capita environmental impact of cities, including by paying special attention to air quality and municipal and other waste management. Furthermore, in SDG 6 under water and sanitation explicitly addresses the problem of waste dumping Consequently, tackling this global waste crisis, by ensuring access to adequate, safe, and affordable solid waste collection services for all and by eliminating uncontrolled dumping and open burning, would constitute a major contribution to sustainable development as defined by the United Nation (UN) SDGs. Table 1 presents these 12 SDGs with their pertinent targets and their links to SWM. 
INTERNATIONAL JOURNAL OF ACADEMIC RESEARCH IN BUSINESS AND SOCIAL SCIENCES Vol. 10 , No. 11, 2020, E-ISSN: $2222-6990$ @ 2020 HRMARS

Table 1 Relationship between Sustainable Development Gaols and Solid Waste Management.

\begin{tabular}{|c|c|c|c|c|}
\hline \multirow[b]{2}{*}{ Driver } & & \multicolumn{2}{|r|}{ Sustainable Development } & \multirow{2}{*}{$\begin{array}{l}\text { Solid Waste Management (SWM) } \\
\text { SWM Related 'Virtual SDG' " }\end{array}$} \\
\hline & & $\begin{array}{c}\text { Sustainable } \\
\text { Development Goal } \\
\text { (SDG) }\end{array}$ & Specific Target & \\
\hline \multirow{3}{*}{\multicolumn{2}{|c|}{ 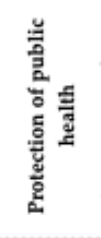 }} & $\begin{array}{l}\text { SDG 11: Sustainable } \\
\text { cities }\end{array}$ & $\begin{array}{l}\text { 11.1 Ensure access for all to adequate, safe, and } \\
\text { affordable basic services; upgrading slums }\end{array}$ & \multirow{3}{*}{$\begin{array}{l}\rightarrow \text { Goal } 1 \text {. Ensure access for all to adequate, safe, and } \\
\text { affordable solid waste collection services. } \\
\text { Uncollected waste is often } d \text { umped in uaterways or burned in } \\
\text { the open air, thus directly causing pollution and } \\
\text { contamination. Waste also clogs the drains, which exacerbates } \\
\text { floods, keeping stagnant water and contributing to } \\
\text { water-borne diseases and malaria. Children are anong the } \\
\text { most vuinerable, so they are affected the most. }\end{array}$} \\
\hline & & $\begin{array}{l}\text { SDG 3: Good health and } \\
\text { well-being }\end{array}$ & $\begin{array}{l}\text { 3.2 End preventable deaths of children under } 5 \text { years } \\
\text { 3.3 End malaria and combat water-borne diseases } \\
\text { 3.9 Reduce illnesses from hazardous chemicals and air, } \\
\text { water and soil pollution, and contamination }\end{array}$ & \\
\hline & & \multirow{3}{*}{$\begin{array}{l}\text { SDG 11: Sustainable } \\
\text { cities } \\
\text { SDG 12: Responsible } \\
\text { consumption and } \\
\text { production }\end{array}$} & \multirow{2}{*}{$\begin{array}{l}11.6 \text { Reduce the adverse environmental impact of cities } \\
\text { special attention to waste management }\end{array}$} & \\
\hline \multirow{7}{*}{ 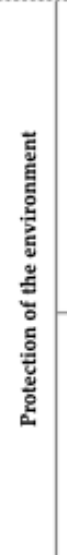 } & & & & \multirow{4}{*}{$\begin{array}{l}\rightarrow \text { Goal 2. Eliminate uncontrolled dumping and open } \\
\text { burning. as the first stepping-stone to achieving } \\
\text { environmentally sound SWM practices. } \\
\rightarrow \text { Goal 3. Achieve environmentally sound } \\
\text { management of all wastes, particularly hazardous } \\
\text { wastes (either chemical or biological hazardous wastes). }\end{array}$} \\
\hline & & & $\begin{array}{l}\text { 12.4 Environmentally sound management of chemicals } \\
\text { and all wastes in order to minimize their adverse } \\
\text { impacts on human health and the environment }\end{array}$ & \\
\hline & & $\begin{array}{l}\text { SDG 6: Clean water and } \\
\text { sanitation }\end{array}$ & $\begin{array}{l}6.3 \text { Improve water quality by reducing pollution, } \\
\text { eliminating dumping and minimizing release of } \\
\text { hazardous materials }\end{array}$ & \\
\hline & & SDG 15: Life on land & $\begin{array}{l}\text { 15.1 Ensure the conservation of terrestrial and inland } \\
\text { freshwater ecosystems and their services }\end{array}$ & \\
\hline & \multirow{3}{*}{ 嵌 } & $\begin{array}{l}\text { SDG 7: Affordable and } \\
\text { clean energy }\end{array}$ & $\begin{array}{l}7.2 \text { Increase the share of renewable energy in the global } \\
\text { energy mix }\end{array}$ & $\begin{array}{l}\rightarrow \text { Goal 3. SWM technologies can derive renewable energy } \\
\text { from (organic) waste. }\end{array}$ \\
\hline & & SDG 13: Climate action & $\begin{array}{l}\text { SDG 13: Take urgent action to combat climate change } \\
\text { and its impacts }\end{array}$ & $\begin{array}{l}\rightarrow \text { Goal 3. Adequate SWM practices can prevent emissions } \\
\text { of large amounts of greenhouse gases. i }\end{array}$ \\
\hline & & $\begin{array}{l}\text { SDG 14: Life below } \\
\text { water }\end{array}$ & $\begin{array}{l}\text { 14.1 Prevent marine pollution of all kinds, in particular } \\
\text { from land-based activities, including marine debris }\end{array}$ & $\begin{array}{l}\rightarrow \text { Goal } 1 \text { and Goal } 2 \text { Extending waste collection to all and } \\
\text { eliminating uncontrolled dunping will prevent waste } \\
\text { (particularly plastics) ending up in the oceans. }\end{array}$ \\
\hline
\end{tabular}

Source : Ljiljana Rodi et al (2017)

\section{A Review of Solid Waste Management in Malaysia}

According to Department of National Solid Waste Management (2012), Malaysians produce an average of 30,000 tons of waste every day, unfortunately only $5 \%$ of it is recycled. Municipal solid waste is managed under the Ministry of Housing and Local Government (MHLG) (Moh \& Abd Manaf, 2014), and according to UNDP (2008), the collections are mostly confined to urban and township areas within the local authority (LA) boundary. For rural area, the collection methods are limited; mostly are self-reliant and rely heavily on disposal by burial in the proximity of each household (UNDP, 2008). The responsibility of solid waste management (SWM) in rural areas does not belong to any specific agency, however the Ministry of Health has taken the initiative in providing technical advice and guidelines to ensure the health and wellbeing of the rural population. Generally, villagers are mostly involved with illegal dumping sites and backyard burning of wastes (Moh \& Abd Manaf, 2014; Mohee et al., 2015). Improper disposal contributes to environmental pollution the outbreaks of vector-borne disease (Tengku Afrizal \& Rozaman, 2015).

The poor (SWM) is not a new issue in Malaysia. It reflects the inefficiency and ineffectiveness of SWM system which includes solid waste storage, collection, logistic, and disposal (Mohd Nasir, 1997; Nadzri \& Larsen, 2012). In Malaysia, SWM is a crucial agenda towards sustainability. Figure 1 depicts the timeline of SWM transition in Malaysia (Sreenivasan et al., 2012; Mughal, 2019). 


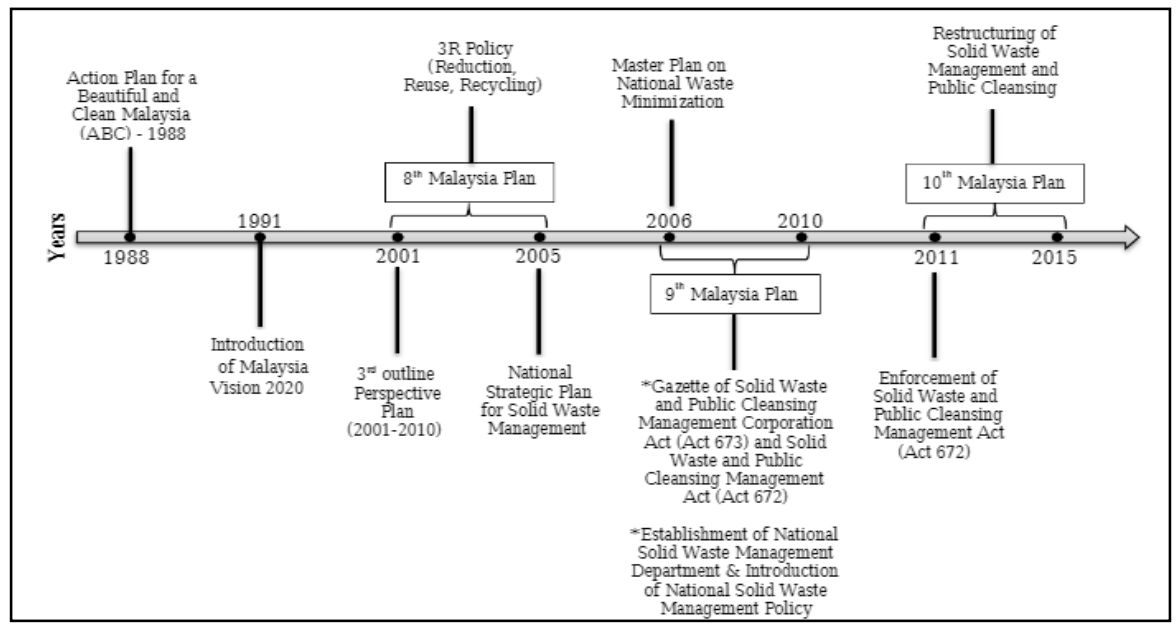

Figure 1 Timeline of Solid Waste Management Transition in Malaysia (Sreenivasan et al., 2012)

The Malaysia's waste composition is dominated by municipal solid waste (64\%), followed by industrial waste (25\%), commercial waste ( $8 \%)$, and construction waste (3\%) (EU- SWMC, 2009). About $80 \%$ of municipal solid wastes are recyclables and are disposed at the landfills (Ministry of Housing and Local Government, 2005). Furthermore, under municipal solid waste category, household waste is among the highest contributors i.e. $70-80 \%$ of the total solid waste composition as found in the landfills (Sumiani et al., 2009). In Malaysia, the traditional method of SWM disposal is via landfilling practice but its dependency is gradually limited due to acute land shortage, aesthetic factor, and pollution arising from odours and pests. Landfill is an area of land, normally derelict, where waste is deposited (Singh et al., 2011) and concentrated for up to 20 years before being permanently sealed. Due to the lack of emphasis on landfill management aspect, Malaysia is currently facing problems associated with landfill pollution and improper waste disposal practice; the latter is considered as one of the three main environmental problems faced by most municipalities, besides water and air pollution (Fauziah \& Agamuthu, 2012). Recently, new problems from both active and closed landfills due to water source pollution have forced the government to form a special cabinet committee to propose a more comprehensive SWM structure, especially within the densely populated regions (Abd Kadir et al., 2013).

Solid wastes in rural area mostly come from residential usage e.g. food waste, food container, can, bottle, paper, newspaper, clothe, garden waste, e-waste, and furniture waste (Franklin Association, 1999). As SWM in rural area is limited, the Ministry of Health (1999) has established four methods that can be applied by the communities in rural area, i.e. storage, collection, transportation, treatment, and disposal (Guidelines for Source Separation of Municipal Solid Wastes, 2005). First, they can store and dispose wastes in nearby areas or house compound by members of the house. Second, they can collect and transport wastes using vehicle to disposal area far from their house or village. Third, the wastes can immediately be taken out and disposed at the nearby disposal area without any storage. Fourth, the wastes can immediately be transported by vehicle to a distant central disposal site or to a community storage bin where collection and final disposal process is carried out by other external party. A fraction of the wastes might have been removed from the waste stream for recycling or reuse purposes. 
Rural communities typically do not run the government-designated programs e.g. waste separation and recycling because their areas are located outside the LA boundary and there is no proper SWM infrastructure (Guideline for Source Separation of Municipal Solid Wastes, 1999). SWM in rural area is also considered as undeveloped and there is no single guideline for SWM in rural area (Ministry of Health, 2005). Thus, if there is any recycling program or systematic SWM in rural area, it is mostly organised by the community itself (Zainon, 2016). To date, there are only a few areas that have applied a systematic SWM that is established and run by the community itself. This has certainly improved the areas' cleanliness and hygiene, and reduce serious diseases caused by mosquito breeding, flies, and mouse (Hamatschek, 2010). In this sense, it is better if the program can bring more benefits to various groups in the society in the terms of economic, social, and environment.

\section{Material and Methodology \\ Description of Kota Tinggi District}

Kota Tinggi is the biggest district in the state of Johor, Malaysia with an area of 3,500 square meters. There are 10 subdivisions in Kota Tinggi with more than 200,000 populations who mostly live in rural areas; 26 traditional villages, 117 joint villages, 29 FELDA settlements, and 5 KEJORA new towns. Most of them are farmers in FELDA settlements, fishermen for those who live near to river estuary, industrial workers, and government servants. On the other hand, the $9^{\text {th }}$ Malaysia Plan stated that FELDA and FELCRA settlers are highly encouraged to be involved in other activities than traditional farming, e.g. systematic replanting of palm oil, integrated village industries, and modern agriculture to attract young people to venture into these areas in the future.

The present study used primary and secondary data for data analysis purpose. The primary data were collected via interviews with relevant agencies in SWN likes District Office and Head of Village. Meanwhile, the secondary data were desktop studies to find the current unsolved issues related to SWM especially in rural areas. Figure 2 shows the flow of the study. 


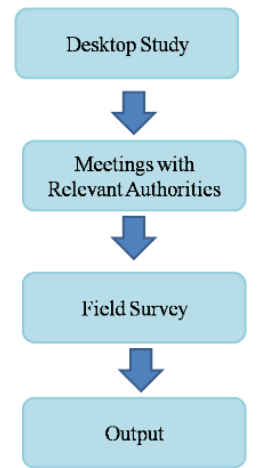

Figure 2 Workflow of the Study

\section{Desktop Study and Meeting with Relevant Authorities}

Data were collected from official websites and published literature. Preliminary information on the number of villages and population in rural areas were obtained from Kota Tinggi District Office, Lembaga Kemajuan Johor Tenggara (KEJORA), and reports published by the Department of Statistics (DOS). Meetings were held with relevant authorities who were dealing with the management of areas outside of the LA service boundaries. The authorities include Kota Tinggi District Office, the Village Development and Security Committee (Jawatankuasa Kemajuan dan Keselamatan Kampung, JKKK or now is known as Village Community Management Council, $M P K K)$ and KEJORA. Existing information were gathered from the authorities, particularly information about the existing household waste management i.e. storage, collection, transportation, and disposal.

\section{Field Survey}

In this study, field survey was employed to analyze the appropriateness of community participation in SWM activities and recycled materials. Traditional villages do not receive any waste collection services from LA. Information on the state of existing disposal sites and the stakeholders involved were also obtained. The field survey was conducted based on ground survey performed in traditional villages in Kota Tinggi district. Data on the location and population of traditional village settlements and contact information for the settlement were gathered and mapped using Google Earth application. Table 2 presents the methods suggested by Danish International Development Assistance (2010).

Table 2 Zoning of Traditional Villages for Provision of Waste Management Services

\begin{tabular}{|l|l|l|}
\hline \multicolumn{1}{|c|}{ Zone category } & \multicolumn{1}{|c|}{ Accessibility } & \multicolumn{1}{c|}{ Proposed solution } \\
\hline $\begin{array}{l}\text { Zone A } \\
\text { (Less } 35 \text { kilometers) }\end{array}$ & $\begin{array}{l}\text { Can be accessed by collection truck for } \\
\text { house-to-house collection }\end{array}$ & $\begin{array}{l}\text { Waste collected house-to- } \\
\text { house }\end{array}$ \\
\hline $\begin{array}{l}\text { Zone B } \\
\text { (Within 35 kilometers) }\end{array}$ & $\begin{array}{l}\text { Can be accessed by collection truck for } \\
\text { bulk collection but local roads are not } \\
\text { suitable for house-to-house collection. }\end{array}$ & $\begin{array}{l}\text { Waste is brought by household } \\
\text { to communal receptacle for } \\
\text { collection. }\end{array}$ \\
\hline $\begin{array}{l}\text { Zone C } \\
\text { (More than } 35 \\
\text { kilometers) }\end{array}$ & $\begin{array}{l}\text { Cannot be accessed by collection vehicles } \\
\text { due to poor road condition or distance. }\end{array}$ & $\begin{array}{l}\text { Local collection and disposal } \\
\text { must be organized. }\end{array}$ \\
\hline
\end{tabular}

Source: Adapted from Danish International Development Assistance (DANIDA), 2010 
From the method suggested by DANIDA and the situation in the field, the traditional villages is divided to three zone that was zone $A, B$ and $C$. The zoning category is to describe the situation in the village especially the road condition. In fact, a proper solid waste management that provide by the local authority requires good road conditions to facilitate the entry of garbage trucks and make collection from house to house. Furthermore, local authority can find a better solution of the solid waste management in the areas. The finding of data collection is shows in result and discussion section.

\section{Result and Discussion}

As shown in Figure 3, the findings of the present study were based on publication reviews, meetings with relevant agencies, and a pilot field survey conducted in Kota Tinggi district, Johor. Overall, there were lacking SWM in rural areas especially for villages in Kota Tinggi district. Two agencies responsible for the public health and social welfare of the rural areas are Kota Tinggi District Office and MPKK.

Kota Tinggi, Johor was the selected area for the pilot field survey as it comprises various types of settlements, e.g. traditional villages, Orang Asli (aborigine) villages, FELDA settlements, KEJORA new towns, and recreational parks. However, this study only selected traditional villages and FELDA settlements due to some constraints. Table 1 illustrates the SWM methods used by the communities there, while Figure 3 shows plotting villages based on the SWM methods.

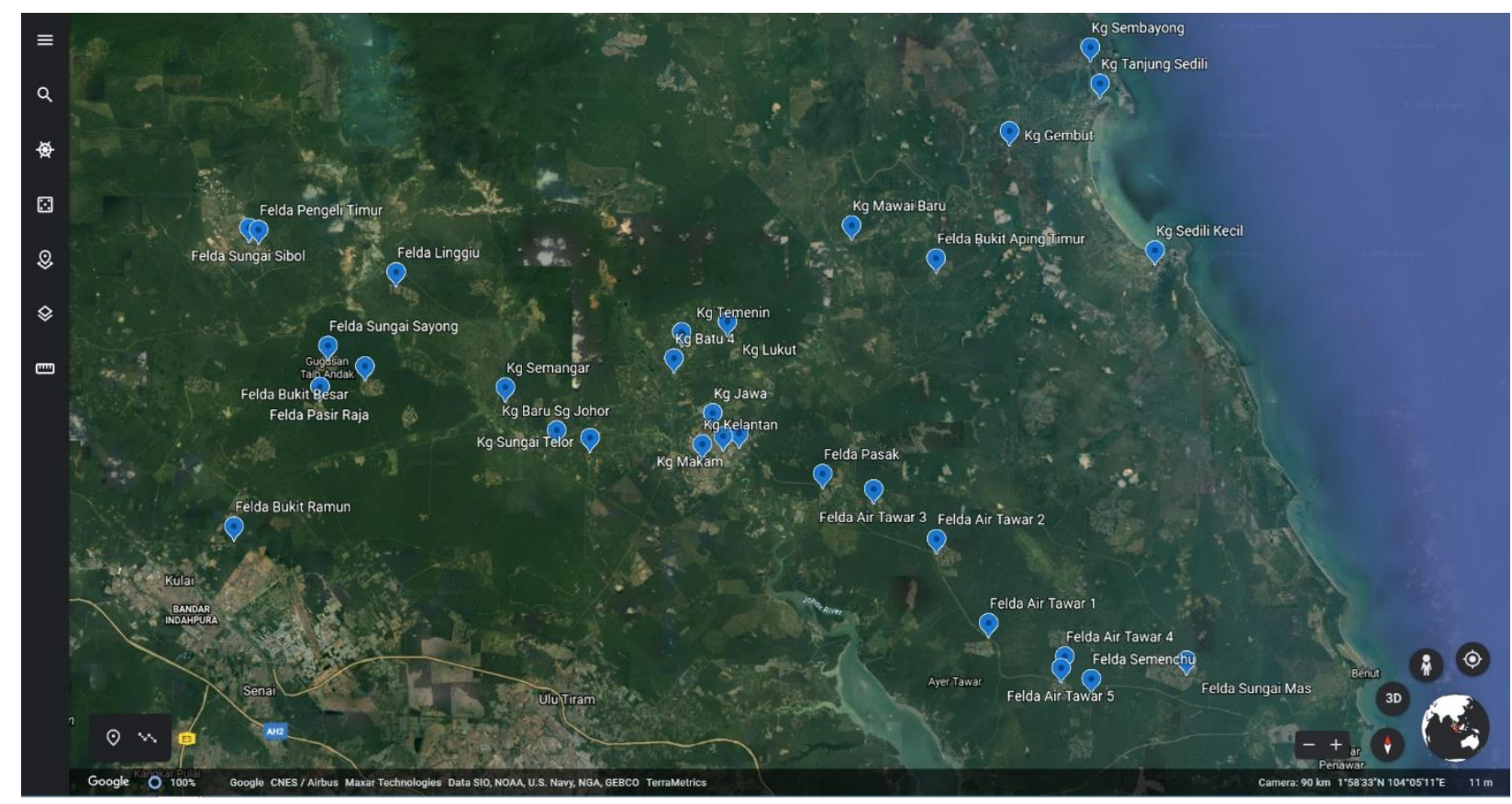

Figure 3 Location of Field Survey (Google Earth, 2017) 
Table 3 Type and Number of Rural Areas Surveyed in Kota Tinggi District

\begin{tabular}{|l|c|c|c|c|}
\hline \multicolumn{1}{|c|}{ Type of rural areas } & $\begin{array}{c}\text { No of rural areas } \\
\text { surveyed }\end{array}$ & SWM & MPKK & $\begin{array}{c}\text { Own- } \\
\text { Initiative }\end{array}$ \\
\hline Traditional villages & $\begin{array}{c}28 \\
(60.86 \%)\end{array}$ & $\begin{array}{c}8 \\
(28.57 \%)\end{array}$ & $\begin{array}{c}3 \\
(10.71 \%)\end{array}$ & $\begin{array}{c}17 \\
(60.71 \%)\end{array}$ \\
\hline FELDA villages & 18 & 16 & 2 & 0 \\
\hline Total & $(39.13 \%)$ & $(88.88 \%)$ & $(11.11 \%)$ & $(0.00 \%)$ \\
\hline
\end{tabular}

Overall, there were lacking SWM in rural areas especially for villages in Kota Tinggi District. Most of the traditional villages (60.71\%) use traditional method like onsite burning, animal feeding, or self-transferred to wheeled dustbins outside of the village, while most of the FELDA settlements (88.88\%) use modern method in which they hire contractor to perform the SWM following a proper, normal schedule.

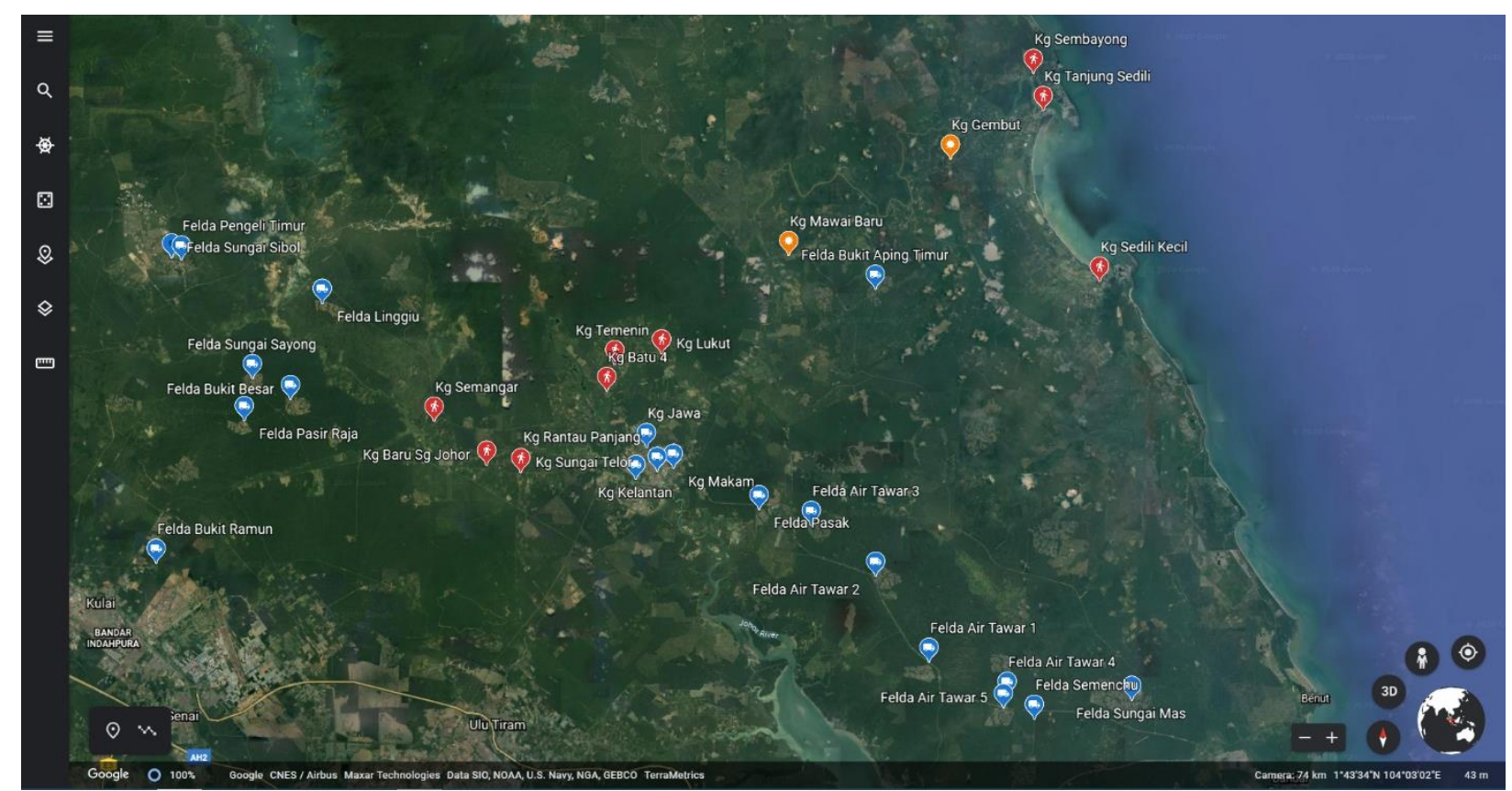

Figure 4 Plots Based on the Methods Practiced by the Communities (Google Earth, 2017)

Uncollected solid waste is a prominent environmental problem in rural areas. In traditional villages, SWM is predominantly guided by the district health officers at their own initiatives. However, due to the absence of sense of responsibility for SWM, a proper storage and disposal of wastes is generally not practiced. Wastes are haphazardly scattered and distributed everywhere in some of the villages. This situation is worsened when contagious diseases e.g. dengue haunt the villagers. In FELDA settlements, SWM is managed by the FELDA's managers in every settlement based on their own initiatives. Table 4 summarizes the findings from the pilot survey in Kota Tinggi district. 
Table 4 Summary of Waste Management Methods by The Community

\begin{tabular}{|c|c|c|c|c|}
\hline \multicolumn{3}{|c|}{ Traditional Villages } & \multicolumn{2}{|c|}{ FELDA Settlements } \\
\hline SWM & MPKK & Own Initiative & SWM & MPKK \\
\hline Storage: & Storage: & Storage: & Storage: & Storage: \\
\hline $\begin{array}{l}\text { Use various } \\
\text { types of waste } \\
\text { bins. }\end{array}$ & $\begin{array}{l}\text { Use various } \\
\text { types of waste } \\
\text { bins. }\end{array}$ & $\begin{array}{l}\text { Use waste bins } \\
\text { for daily waste } \\
\text { then disposed. }\end{array}$ & $\begin{array}{l}\text { Use various } \\
\text { types of waste } \\
\text { bins. }\end{array}$ & $\begin{array}{l}\text { Use various } \\
\text { types of waste } \\
\text { bins. }\end{array}$ \\
\hline $\begin{array}{l}\text { Collection: } \\
\text { Collected by } \\
\text { SWM contractor } \\
\text { two times a } \\
\text { week for solid } \\
\text { waste and once } \\
\text { a week for } \\
\text { recycled waste. }\end{array}$ & $\begin{array}{l}\text { Collection: } \\
\text { Collected by } \\
\text { private } \\
\text { contractor two } \\
\text { times a week for } \\
\text { solid waste and } \\
\text { once a week for } \\
\text { recycled waste. }\end{array}$ & $\begin{array}{l}\text { Collection: } \\
\text { No collection. } \\
\text { For those who } \\
\text { use bins, they } \\
\text { will self-transfer } \\
\text { to wheeled } \\
\text { dustbins outside } \\
\text { of the village. }\end{array}$ & $\begin{array}{l}\text { Collection: } \\
\text { Collected by } \\
\text { SWM } \\
\text { contractor two } \\
\text { times a week } \\
\text { for solid waste } \\
\text { and once a } \\
\text { week for } \\
\text { recycled }\end{array}$ & $\begin{array}{l}\text { Collection: } \\
\text { Collected by } \\
\text { private } \\
\text { contractor one } \\
\text { or two times a } \\
\text { week for solid } \\
\text { waste and } \\
\text { once a week } \\
\text { for recycled }\end{array}$ \\
\hline Recycling: & Recycling: & Recycling: & waste. & waste. \\
\hline $\begin{array}{l}\text { Practiced by the } \\
\text { self-initiated } \\
\text { communities. }\end{array}$ & $\begin{array}{l}\text { Practiced by the } \\
\text { self-initiated } \\
\text { communities. }\end{array}$ & $\begin{array}{l}\text { Practiced by } \\
\text { own initiative. } \\
\text { Disposal: }\end{array}$ & $\begin{array}{l}\text { Recycling: } \\
\text { Practiced by } \\
\text { the self- }\end{array}$ & $\begin{array}{l}\text { Recycling: } \\
\text { Practiced by } \\
\text { the self- }\end{array}$ \\
\hline $\begin{array}{l}\text { Disposal: } \\
\text { LA landfill }\end{array}$ & $\begin{array}{l}\text { Disposal: } \\
\text { LA landfill }\end{array}$ & $\begin{array}{l}\text { Animal feeding, } \\
\text { in a pit with } \\
\text { cover, and } \\
\text { onsite burning. }\end{array}$ & $\begin{array}{l}\text { initiated } \\
\text { communities. } \\
\text { Disposal: } \\
\text { LA landfill }\end{array}$ & $\begin{array}{l}\text { initiated } \\
\text { communities. } \\
\text { Disposal: } \\
\text { LA landfill }\end{array}$ \\
\hline
\end{tabular}

Since there were absence of linkages among SWM and rural areas, a case study was employed to assess the applicability of the zonal system, and if such a system was employed, how many villages would be considered applicable. Based on the method, the villages in each zone and the actual travelling distance from each village to the nearest LA landfill that is Batu Empat Landfill are tabulated in Table 3. This study was conducted with three zones in Kota Tinggi district based on the accessibility for truck collection of SWM using Google Earth. Zone A is for the communities that can be accessed by collection truck for house-to-house collection and the result shows most of them were FELDA settlements. Zone B represents communities that can be accessed by collection truck for bulk collection, but local roads are not suitable for house-to-house collection and the result shows most of them were traditional villages. Zone $C$ shows the communities that cannot be accessed by collection vehicle due to poor road condition or distance. Figure 4 shows the zoning areas, A, B, and C based on the accessibility or road condition. 
Table 5 Zoning of Rural Areas for Provision of Waste Management Services

\begin{tabular}{|l|c|c|}
\hline \multicolumn{1}{|c|}{ Zone Category } & No of Villages & $\begin{array}{c}\text { Percentage } \\
\text { of Villages } \\
\text { (\%) }\end{array}$ \\
\hline $\begin{array}{l}\text { Zone A } \\
\text { (Less than 35 kilometers) }\end{array}$ & 26 & 57 \\
\hline $\begin{array}{l}\text { Zone B } \\
\text { (Within 35 kilometers) }\end{array}$ & 15 & 32 \\
\hline $\begin{array}{l}\text { Zone C } \\
\text { (More than 35 kilometers) }\end{array}$ & 5 & 11 \\
\hline
\end{tabular}

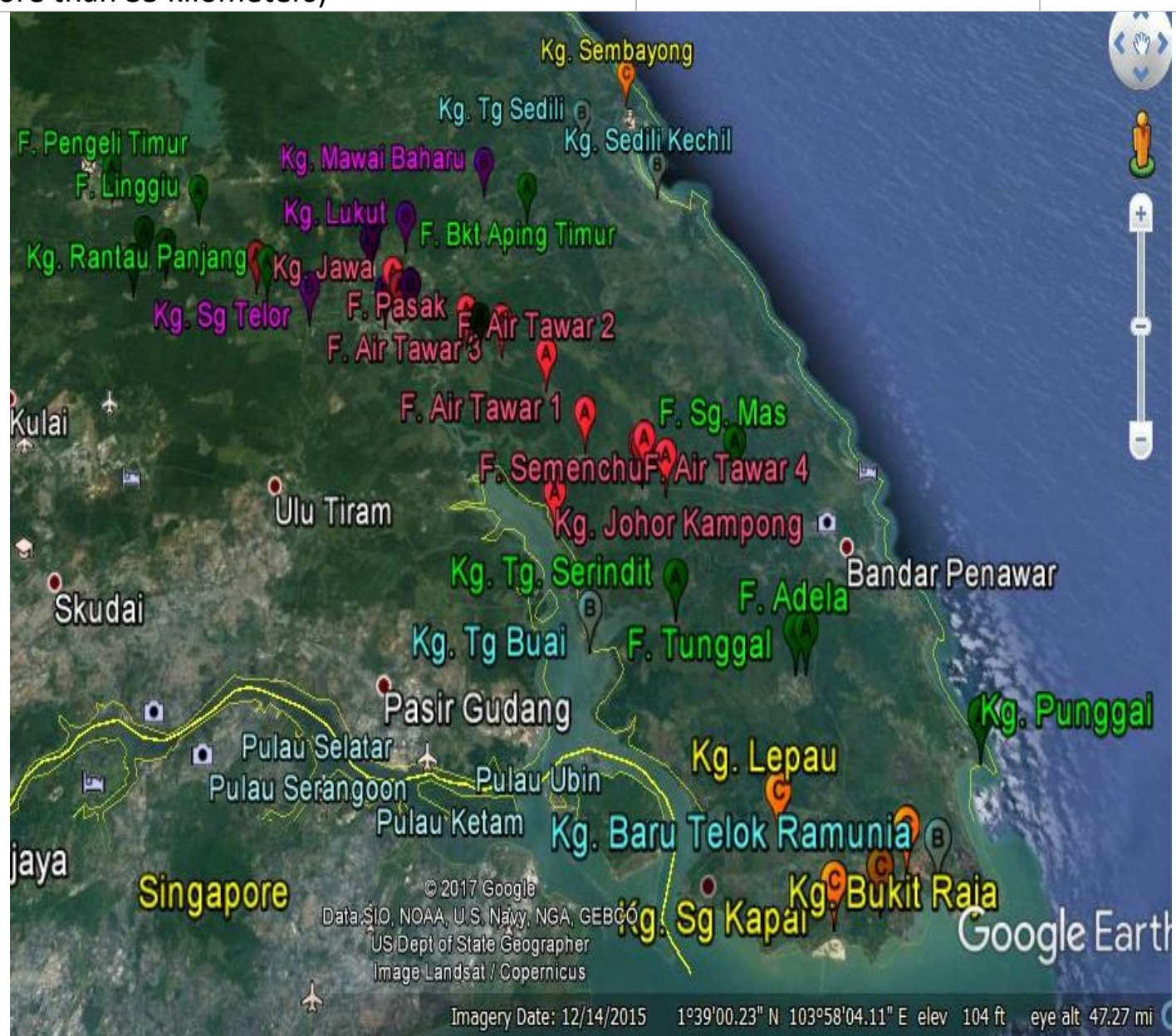

Figure 5 Zoning Areas A, B, And C Based on The Accessibility or Road Condition (Google Earth, 2015)

Overall, there is a lack of SWM in these rural areas. The communities near to LA boundary have a well-managed SWM served by either private contractor or contractor appointed by MPKK. Hence, the rest still use traditional methods like onsite burning, animal feeding, or selftransferred to wheeled bins. Unlike the LA's SWM, where households pay assessment tax to LA for handling the waste, there is currently no collection system in rural areas outside the LA's services boundaries.

Uncollected solid waste is one of the most visible environmental problems in rural areas. In traditional villages, SWM is predominantly guided by the district health officers at their own initiatives. The problem presented in this study occurs due to the lack of education and 
awareness, as well as the absence of specific responsibility for SWM. Meanwhile, FELDA settlements have a well-managed SWM by appointing contractors to handle the solid waste.

This study recommends zonal method to be applied for areas that can be accessed by either collection truck based on different road conditions and distance from LA landfill. Results show that most of the communities in rural areas can be accessed by collection truck. Nonetheless this also depends if the communities are ready to pay some charges to appoint contractor. The $3 \mathrm{R}$ (reduce, reuse, and recycle) activities can be conducted by communities by their own initiatives; once-a-week collection for areas with contractor, and self-transfer to recycle centre for areas without contractor.

\section{Conclusion}

In conclusions, it is great knowing that the government has implemented SWP program involving the communities. However, the increasing amount of wastes does not only come from residential areas, but also from other industrial sectors. Therefore, the government has to be persistent to spread awareness and to educate people about waste treatment and recycling, in which the focus should be given on both urban and rural areas. Next, with the advancement of technology and development, it is possible for the government and responsible agencies to successfully find ways and implement SWM in rural areas. In short, countries with good SWM have greatly benefited their citizens in many different ways, hence necessary actions must be taken to achieve the "clean country" goal in 2020.

\section{Acknowledgement}

The author is grateful for the support and assistance given by the research members group, Nur Khairiyah Mohammad, Salfarina Samsudin and Norhazliza Abd Halim to perform and conduct this research. This work was supported by a research grant endowed by Universiti Teknologi Malaysia (Q.J130000.2527.15H68). This support is gratefully acknowledged.

\section{Corresponding Author}

Robiah Suratman

Faculty of Built Environment and Surveying, Universiti Teknologi Malaysia, 81310 Johor

Bahru, Johor, Malaysia.

Email: robiah@utm.my

\section{References}

Abas, M. A., \& Wee, S. (2014). Municipal solid waste management in Malaysia: An insight towards sustainability. Available at SSRN 2714755.

Afrizal, T., \& Hassan, M. N. (2001). Privatisation of solid waste management in Malaysia: Is full privatisation the answer to solid waste management issues. In Proceeding on National Seminar on Environmental Management.

Agamuthu, P. (2011). Policy evolution of solid waste management in Malaysia.

Ahmadi, M., Hashim, H. S., Mohamed, A. F., \& Moharamnejad, N. (2013). Toward communitybased waste management: Tehran as a case example. Middle-East Journal of Scientific Research, 15(8), 1102-1107.

Fauziah, S. H., \& Agamuthu, P. (2012). Trends in sustainable landfilling in Malaysia, a developing country. Waste Management \& Research, 30(7), 656-663. 
Hamatschek, E., Entwicklungszentrum, A., Tee, M. S. S. S., \& Faulstich, I. M. (2010). Current practice of municipal solid waste management in Malaysia and the potential for wasteto-energy implementation. In ISWA World Congress (pp. 1-13).

Hoornweg, D., \& Thomas, L. (1999). What a waste: solid waste management in Asia. The World Bank.

Indrianti, N. (2016). Community-based solid waste bank model for sustainable education. Procedia-Social and behavioral sciences, 224, 158-166.

Jha, A. K., Singh, S. K., Singh, G. P., \& Gupta, P. K. (2011). Sustainable municipal solid waste management in low income group of cities: a review. Tropical Ecology, 52(1), 123-131.

Kadir, S. A. S. A., Yin, C. Y., Sulaiman, M. R., Chen, X., \& El-Harbawi, M. (2013). Incineration of municipal solid waste in Malaysia: Salient issues, policies and waste-to-energy initiatives. Renewable and Sustainable Energy Reviews, 24, 181-186.

Ministry of Housing and Local Government Malaysia. (2005). National Strategic Plan for Solid Waste Management: The Strategic Plan (Volume 1). Kuala Lumpur: Ministry of Housing and Local Government Malaysia.

Ministry of Housing and Local Government. (2005). National Strategic Plan for Solid Waste Management. Malaysia.

Mohee, R., Mauthoor, S., Bundhoo, Z. M., Somaroo, G., Soobhany, N., \& Gunasee, S. (2015). Current status of solid waste management in small island developing states: a review. Waste management, 43, 539-549.

Moh, Y. C., \& Manaf, L. A. (2014). Overview of household solid waste recycling policy status and challenges in Malaysia. Resources, Conservation and Recycling, 82, 50-61.

Nathanson, J. (2015). Solid-waste management. Encyclopaedia B ritannica. Retrieved from http://www.britannica.com/technology/solid-waste-management

Noor, Z. Z. (2016). Towards Sustainable Household Waste Management in Urban Areas: Determinants That Hindered the Recycling Activities in The City of Johor Bahru, Malaysia.

Village, P. K. S. (1999). Characterization of Municipal Solid Waste in the United States: 1998 Update.

Seow, T. W. (2009). Masalah Pengurusan Sisa Pepejal di Daerah Batu Pahat, Johor (Doctoral dissertation, PhD Thesis, Universiti Kebangsaan Malaysia).

Wee, S. T. (2012). New perspective of integrated solid waste management in Malaysia. In Proceeding 3rd International Conference on Human Habitat \& Environment in the Malay World (pp. 19-20).

Solid Waste and Public Cleansing Management Corporation. (2011). Implementation of Solid Waste and Public Cleansing Management Act (Act 672), Annual Report 2011 (Chapter 4). Kuala Lumpur: Solid Waste and Public Cleansing Management Corporation.

Solid Waste Management and Public Cleaning Act. (2007). Malaysia.

Sreenivasan, J., Govindan, M., Chinnasami, M., \& Kadiresu, I. (2012). Solid waste management in Malaysia: a move towards sustainability. Waste management-An integrated vision, 5570.

Sumiani, Y., Onn, C. C., Mohd, D., \& Wan, W. Z. (2009). Strategies for planning of optimum landfill sitting decision making. Journal of Sains Malaysiana, 457-462.

World Bank. (1999b). Technical Guidance Report: Municipal Solid Waste Incineration. Washington: The World Bank.

Yahaya, N., \& Larsen, I. B. (2008). Federalising solid waste management in peninsular Malaysia. In Proceeding of International Solid Waste Association (ISWA) World Congress, Singapore. 
Yousuf, T. B., \& Rahman, M. (2007). Monitoring quantity and characteristics of municipal solid waste in Dhaka City. Environmental monitoring and assessment, 135(1-3), 3-11.

Zaman, A. U. (2014). Measuring waste management performance using the Zero Waste Index: The case of Adelaide, Australia. Journal of Cleaner Production, 66, 407-419. 